UDC 81'37; 003; 81'22

DOI https://doi.org/10.24919/2308-4863/39-2-27

\author{
Lamıa MUGALOVA, \\ orcid.org/0000-0003-2433-5334 \\ Doctoral Student, \\ Lecturer at the Linguoculturology Department \\ Azerbaijan University of Languages \\ (Baku, Azerbaijan)mugalova83@mail.ru
}

\title{
SPATIAL FUNCTIONAL-SEMANTIC FIELD IN THE ENGLISH AND THE AZERBAIJANI LANGUAGES
}

The article is devoted to the theory of the functional-semantic field of a language. It describes the functional-semantic field of the languages as one of the methods, which characterizes the semantic space of the language. It speaks of the same phenomenon in English and Azerbaijani by demonstrating examples from both languages. The author finds many identical features and differences in the functional-semantic of the two languages and sometimes appeals to the materials of the Russian language, too. The location and displacement micro fields are separated in the horizontal structure of functional-semantic spatial field of Azerbaijani and English.

The grammatical units of the functional-semantic field of the Azerbaijani consist of suffixes of the spatial cases of the nouns. The space has a grammatical nuclear and is differentiated with high productivity by creating spatial meaning as a grammatical means.

In the present stage of development of linguistics attention to the study of systemic relations and functional aspects of languages has grown. The theory of functional-semantic field, which has emerged in functional grammar, is applied to the study of different categories of language. It has been defined that the functional-semantic field should be analyzed like this: "Functional-semantic field is a bilateral formal-content unity formed by lexical, grammatical and word-building elements, which belong to the same semantic field mutually connected with them and grammatical (morphological and syntactic) means". It is noteworthy to mention that any semantic category forms the basis of a functional-semantic field and the semantic invariant representing this category combines different kinds of language means and forms the nuclear of their interaction. Different studies have dealt with the functional-semantic theory. The researches on this field are known to be studied different issues of spatial theory and different spaces have been studied on the basis of the materials of different languages.

Key words: space, place, functional-semantic field, locative, formal, content.

Ламія МУГАЛОВА, orcid.org/0000-0003-2433-5334 докторант,

викладач кафедри лінгвокультурології Азербайджанського університету мов (Баку, Азербайджан)тиgalova83@mail.ru

\section{ПРОСТОРОВЕ ФУНКЦІОНАЛЬНО-СЕМАНТИЧНЕ ПОЛЕ В АНГЛІЙСЬКІЙ ТА АЗЕРБАЙДЖАНСЬКІЙ МОВАХ}

Статтю присвячено теорії функціонально-семантичного поля мови. Описано функціонально-семантичне поле мов як один із методів, щзо характеризує семантичний простір мови. Він говорить про одне і те ж явище англійською та азербайджанською мовами, демонструючи приклади з обох мов. Автор виявляє багато однакових рис та відмінностей у функиіонально-семантичній характеристиці двох мов, а іноді також звертається до матеріалів російської мови. Мікрополя розташування та переміщення розділені в горизонтальній структурі функціонально-семантичного просторового поля азербайджанської та англійської мов.

Граматичні одинииі функиіонально-семантичного поля азербайджанської мови складаються із суфіксів просторових відмінків іменників. Простір має граматичне ядерне середовище і відрізняється високою продуктивністю шляхом створення просторового значення як граматичного засобу.

На сучасному етапі розвитку мовознавства зросла увага до вивчення системних відносин та функиіональних аспектів мов. Теорія функціонально-семантичного поля, щио виникла у функиіональній граматиці, застосовується для вивчення різних категорій мови. Визначено, щзо функиіонально-семантичне поле слід аналізувати так: функціонально-семантичне поле - це двостороння формально-змістова єдність, утворена лексичними, граматичними та словотворчими елементами, які належать до одного і того ж семантичного поля, взаємопов'язаного з ними, і граматичні (морфологічні та синтаксичні) засоби. Примітно згадати, щзо будь-яка семантична категорія становить основу функціонально-семантичного поля, а семантичний інваріант, шцо представляє иџю категорію, поєднує різні види мовних засобів та формує ядро їх взаємодії. Різні дослідження займалися функціональносемантичною теорією. Дослідження у иій галузі, як відомо, вивчали різні питання просторової теорії, а різні простори вивчали на основі матеріалів різних мов.

Ключові слова: простір, місие, функціонально-семантичне поле, локатив, формал, зміст. 
Introduction. Functional-semantic field is known to be one of the structural methods of the spatial meaning in the language. The semantic field allows regulate the volume of lexico-semantic and grammatical information in the study of central and peripheral language units used in the expression of different meanings. It is much easier to identify the areas of the grammatical category. In general, the development of the history of the theory of semantic field can be divided into two stages. The first stage covers the studies conducted by Q.Insen, I.Trir, L.Vasgerber, V. Porsig, O.Dukhachenko and others. These scholars look upon the semantic field as a collection of meaningful units covering a certain area of human experience.

Spatial or locative category is a situational-predicative category; it helps to identify the space and location of the object. The category of space drew the attention of linguists long ago, they strove to determine the methods of expression of space and its types (Boldirev,2000:212). The space, which is the location of an object or action, has become the object of studies in general linguistics, text linguistics, functional and cognitive grammar.

The organization of the language material in functional grammar is approached from two points of view: 1) semasiological (from form to content). Such an approach to the organization of language units leads to the linear structure. Analysis of meanings covers grammatical units, their categories and forms; 2) homonymological (from content to form); in this case the linear construction of the material is avoided; the language material is analyzed within logical-semantic groups. In contemporary linguistics preference is given to the methodology of mixed approach. At first the functional-semantic field is built on the basis of meanings of language forms and then the meanings expressed by language means of the field are subjected to semantic analysis. There are two types of functional-semantic field: 1) functionalsemantic field based on morphological core, which is the same with functional-semantic categories (temporarily, modality, personality, spectacularly, etc.); 2) functional-semantic invariant fields. In the field of functional-semantic invariant there exist only the elements of one level and they form the simple grammatical or lexical field. There is no juxtaposition in the relations of functional-semantic and grammatical fields. The only difference between them is that the grammatical field refers only to the grammatical level. But functional-semantic field covers a wide sphere of language and includes both the grammatical categories and elements of different levels of the language having functional-semantic similarity. Different levels of language (lexical, syntactic, morphological, world build- ing) play the role of a criterion for distinguishing the functional-semantic field. In accordance with the spatial theory the morphological categories are presented by the same language units depending on their functions. These units take part in the context in interrelation for the expression of certain semantic relations.

Analyses. Spatial functional-semantic category and semantic functions represent the semantic content of spatial relations. The locative (spatial) category covers a certain type of semantic relations, here the interrelation of things and events of the reality is realized in a certain form. The category of locative (spatial) covers the certain types of semantic relations and mutual interaction of objects and actions of reality is realized.

A certain form of interaction implies spatial relations in which one of the components plays the role of an orientation of one component for the other one. In general, the locative and spatial relations are much broader notions. Locality is one of the the complicated types of spatial relations and is directly connected and chosen for being in close relation to the location.

The specificity of expression of of spatial relations in language emerges differently in different languages. For example, for the expression of this category in the structure of the grammar of the English language there are no special means. We speak of those means, which express the spatial relations independently and explicitly. In Azerbaijani there is also no grammatical spatial category. It is necessary to mention that in the allusive paradigm of the category of case three cases such as dative (yönlük), locative (yerlik), initial (çıxışlıq) take part in the expression of spatial relations, and it is not accidental that they are called spatial (məkani) cases.

The locative functional-semantic field is a bilateral unity and has the plane of expression and content. In the plane of content spatial reference is determined by the semantic category. The plane of expression is represented by different units of the levels of language, which realize the functions referring to the semantic sphere of locality.

The functional-semantic locative field is neutral from the point of view of gender. It leads the functional-semantic locative field into the division of two micro fields, i.e., replacement and displacement. Localizes play an important role in spatial relations. In static and dynamic spatial relations the chosen Localizes of the object may have static or active relations (Streneva, 2008:137).

Discussions. The space of the event or process (action) is static. To be in some space, or within the boundaries of a given space means that the movement is in the relation of replacement in that space. 
Inthemajorityofcases thespecific featureofthemicro space constituents of location does not have an independent functionality, they function in close contacts.

S. Abdullayev writes: "The compound hierarchical structure of the functional-semantic space is built on the principle of center-periphery (Abdullayev 1998, p.190). The spatial constructions are used as an adverbial modifier of place along with different semantic verb groups. They form the nuclear of the micro space and express locality explicitly (Tahirov, 2007:98).

M.Kunijev writes that adverbial modifiers explain the birth of an action or feature from different points of view and become secondary members of sentences (Kunijev, 2004:166). The adverbial modifies of place are expressed by adverbial modifiers, nouns indicating locality, combinations with nouns, words or word combinations with post positions, interrogative pronouns. E. Paducheva has her own point of view in this matter. She writes that the adverbial modifier of place is subordinate to the predicate or to another member of the sentence expressed by a verb (Paducheva, 2000a:239). In relation to the modifier of place it is necessary to note that sometimes the subordination is very weak. K.Pereverzev states his point of view like this: "It is connected with such a fact that the adverbial modifier of place characterizes the condition of how the action takes place" (Pereverzev, 2000b:255). In comparison with other adverbial modifiers the adverbial modifier of place is more independent. When the verb requires the specification of of the place, the adverbial modifier of place becomes more closely attached to it. In English it is used in the post position, in Azerbaijani in the preposition.

According to A.Bondarko's oppinion the meaning of the verb is the determinant of static and dynamic spatial relations, because the static or dynamic nature of the verb finds its expression in its meaning (Bondarko, 1983:108). Therefore, the meaning of the verb forms the communicative center of sentence, pertaining to the micro space of placement or replacement is determined on the basis of semantics (Bondarko, 1984:36).

The main type of relations in the micro space determines the space where the action takes place. The nouns connected with the localization of an event or an action on a space, which indicate the location of an event or action, are very important for the expression of spatial relations.

The functional-semantic area is a hierarchical sphere, and if the spatial sphere is taken into account, it is important to discover the language media, and to place them in that space. It is very important to determine the spheres of location and functional-semantic stratification of words. The sphere of functional-semantic locality is complicated and has its own structure. Its components are interconnected with paradigmatic relations. This sphere is multi-dimensional. Different elements take part in its organization. As a semantic dominant lexical units form the nuclear, the general, the invariant meaning, its lexems that are expressed by lexical units. The common element inherent to corresponding ranks that is called semantic theme (Solovikh, 2010:86). From this point of view the nuclear of the locative space are the the polysemantic words "space" and "place". These words are synonymous. The whole volume of the corresponding notion and the maximal concentration of traits find their reflection in their semantic structure. To prove it, it is necessary to compare the meanings of the Azerbaijani words "mokan" (space) and "yer" (place). The explanatory dictionary of the Azerbaijani language gives the following explanations for them:

Məkan (n) (space) 1) a dwelling of a man or a place where something on which someone sits; a homeland. 2) in general, a place; 3) (in philosophy) one of the main objective forms of matter characterized by its presence, volume and size; category of space; 4) the category of space and time (15).

The word "space" has 26 meanings in this dictionary. They are the following: 1) planet; 2) upper crust of the earth; 3) area on which one stands; 4) country, area, homeland; 5) house, residence, flat, etc. (15).

The words /space/ and /place/ in the English and Azerbaijani dictionaries are defined like the followings:

space (adj) cosmic; (n) place, cosmos, destination, area;

place $(n)$ area, destination, city, flat, square, seat; (v) to place, to hold a place, to count, to assign, to put money, to raise one's voice, to put;

It is necessary to highlight that the need of looking at the other dictionaries is meant to be important to be paid attention to in order to get a complete idea of the circle of meanings of the English words. In “Большой англо-русский словарь" edited by I. Galperin the mentioned words have been defined as:

space (n).1) length, distance, space, place; a space of ten feet -10 futluq məsafə; 2) place (the place of any subject): the piano takes up too much space - royal həddən çox yer tutur; 3) (philosophy) area; 4) distance; period; interval; 5) period of time; 6. cosmos; 7. (math) row; 8. (math.) 9) space; 10) cosmos; 11) (poligraphy) gap, distance, etc. (14).

place (n). 1) land; 2) land, city, station; 3) land, point on the surface, space;

4) ordinary, traditional place; 5) seat, place (in the classroom, at the cinema); 6) page; 7) place, area; 8) (in titles) 1) space; 9) a small street, sidestreet; 10) property; 11) building, room, place; 12) house, flat; 13) property, suburban house, garden; 14) 
old-fashioned. dam; 15) duty, workplace; 16) situation; 17) 1 st and 2nd place in sports prizes; 18). mining camp; 11. (math.) degree (15).

The lexical-semantic centers of location of the micro-field in both Azerbaijani and English are the words space and place. One of the main properties of localizes is its static character in comparison with the object. In modern English the main ways of expression of localize are the spatial nouns. In Azerbaijani and English the nouns like kand, şəhər, ev, otaq (country, city, town, house, room) are used fore more accurate expression of the space. There are combinations with other nouns in both languages, and they express the meaning less accurately at a certain degree. There are not only spatial meanings, but also objective meanings in the semantic structure of these nouns. For instance, the names of different material objects (furniture, clothes, parts of the body, dishes and etc.) are used in spatial phrases. The spatial nouns express the location of the subject and actions. In these cases prepositions and different verbs are used in English. But in Azerbaijani the suffix of the dative case is added to show the location.

A nuclear zone lies around the words space (məkan) and place (yer). Because of the nouns within these zones there emerges a number of groups: 1) nouns expressing common spatial meanings very much connected with meanings which are divided into several levels; they include areal with a narrow meaning of space, border, zone, boundary, relief, etc., as well as the words formed with the words expressing the meaning of "yer" (land, place space); 2) all the words expressing the the geographical meanings, such as universe, earth, cosmos, atmosphere, ocean, moon, sun, continent, mainland, meridian, equator, etc.; 3) generalized names of localized events: punkt (destination), nöqtə (area), sahə (field, area), bölgə (region), etc.

According to their structures functional semantic spaces are multilayered both horizontally and vertically. The precision of the structure of the field is carried out in four main directions: 1) hadisə (event); 2) landşaft (landscape); 3) dinamik (dynamic); 4) parametrik (parametric) (Fedoseeva, 2012:50).

The words such as ev (house), mağaza (shop), bağ (garden), park (park), institut (institute), məktəb (school) and others are used as concertizes of space of the event. For instance, məktəbdə (at school), evdə (at home), bağda (in the garden), parkda (in the park), etc. The landscape group includes such words as çay (river), göl (lake), meşə (forest), dağ (mountain), vadi (valley) etc. Dynamic and parametric groups are the main members of the space. The verbs of dynamism such as aparmaq (to take), çıxarmaq (to draw, to take $o u t$ ), gatirmok (to bring), etc., express the dynamism of location. Parametric concertize of location are the names associated with multidimensional spaces like /width/, /abyss/, /height/, etc.

The words with narrow meanings expressing objects form the periphery zone far from the nuclear of the space. The far peripheral zone includes the followings: 1) common meaningful nouns (place + condition, place + cover, place + external shape, etc.), for example, asphalt, landing, slopes etc; 2) figurative meaningful nouns; 3 ) derivative nouns; for example, a maternity hospital, a rest house, a beauty salon, a gym, etc.; 4) phraseological units with spatial meanings.

Each concrete space requires individual approach. Firstly, it is important to determine the components, in other words, the language media comprised by that space, their groups and structures. Here it is necessary to determine the center and periphery, the hierarchy of the relations among the semantic categories, composition of semantic categories, their hierarchy. Along with it, the units of different levels interact depending on their features. This interaction, which emerges in speech, shows that such units are inclined to interaction. It is not a pure contextual phenomenon, but an immanent property of the units of language and actualizes in the process of speech. The units of language of different levels very often combine because of their functions, but not because of the notion, which are extra linguistic in nature. They fulfill this function not because of their assignment, but on the basis of identity of the meaning. The above mentioned shows that the space as a system belongs to language. The structure of space does not depend on speech, but it emerges in speech.

L. Fedoseeva described the locative functional-semantic field as polycentric and classified five types of spatial meanings: 1) localization of the events and situations); space (they were sitting in the room); action (He goes to school); presence by showing the space (there were two persons in the room); 2) dynamic localization of the action (dynamic spatial relations); trajectory of movement; specifiers (turned right on the street); 3) the place of the objects compared to each other (orientation and lokum); 4) localization according to the subject: distant / close; specification on the basis vertical and horizontal arrows; display of the subject as an orientation during the movement of objects; 5) parametric locality: symmetry (upwards-downwards, forward-backward); center periphery; the lower or upper part of the lokum (on the top of the hill) (Fedoseeva, 2012:12). It is difficult to say that the suggested five spatial relations cover of all the possible cases.

G.Shur explains the difference between displacement and direction as follows: if the subject is located at one point in space at a certain time and is at another 
point at a different time, it is displacement. If there is a boundary in the space that separates it into two parts, and the subject is first in its first and then in its second part, this is the direction (Shur, 1974:57). Thus, if localization is possible at different points in the space, these are only the starting (exit) and end (entry) points in the direction.

The field of the functional-semantic locality of both Azerbaijani and English languages is meant to be a complex multidimensional and is determined by the functions of its constitutors. Constituents are said to be distributed irregularly across micro-sectors. The locative field of English is known to be polycentric, and its core is organized by means of the syntactic level. One of the nuclear centers is composed of spatially meaningful noun compounds and verbs belonging to different semantic groups. Such constructions explicitly realize spatial relations. In the English nuclear zone, spatially meaningful constructions are formed from the combination of space aprons and names. Names denoting space are also distinguished by their activity (Azizova, 2017:147).

The study of spatial relations requires the consideration of the locative situation, too. Locative condition is presented by three components (the localized subject,the locating predicate). It is clear that the object can also be locaized, therefore the subject is taken in a broader sense. The locality covers the following categorical conditions: 1) the subject is motionless or moves within the boundaries of the space; in which case the point where the subject is located is either explicitly stated or described with the help of a certain orientation; 2) the subject acts in a certain part of the space and does not go beyond the boundaries of the space; 3 ) the subject goes beyond the boundaries of the described space; 4) the subject enters into the described space. The latter is extensive in comparison with model related to the localization condition and includes some specific points.

The two main forms of spatial meaning divide it into two segments. The first segment is a place, but the second is a direction. As we know, the segment of place is divided into location and displacement micro fields. The segment of direction is divided into the starting and ending micro fields of action. Dynamism is obvious in the segment of direction and it requires explaining the reason why the displacement is not included in that segment. If localization is possible at different points of the space in displacement, this is only the starting (exit) and ending (entrance) points in direction.

The functional-semantic spatial field of both Azerbaijani and English is a multidimensional complex and is appointed due to the functions of its constit- uents. The constituents are irregularly distributed on the micro fields. The spatial field of English is poly centric and its nuclear is organized by means of the syntactic level. One of the nuclear centers consists of substantive collocations and verbs of different semantic groups. Such constructions explicitly realize the spatial relations. There are a lot of spatial constructions created with the combination of spatial prepositions and names in the nuclear zone of English. Spatial names also differ in usage (Azizova, 2017:150).

The location and displacement micro fields are separated in the horizontal structure of functional-semantic spatial field of Azerbaijani and English.

The grammatical units of functional-semantic field of Azerbaijani consist of suffixes of spatial cases of noun. The space has a grammatical nuclear and is differentiated with high productivity by creating spatial meaning as a grammatical means.

Conclusions. Real space has three dimensions. Objects are located in the space according to these three dimensions. In a number of sciences, such as mathematics, the concept of multidimensional space is used.

Topological characteristics include continuity and continuity, size, coherence, metric characteristics include curvature, finitude, infinity, isotropic, homogeneity.

Just as material objects can be located in space, imaginary objects can also be located. Man can build any object in his imagination and imagine its location in space. Logically imagined space has no material existence.

The categories of space and time are in constant contact with each other. In space, time, shape, structure and size are stable in contact with surrounding objects. Changes in the parameters of a particular space are possible over time. This aspect is more specific to the place where a person is located, which is more described, talked about.

In the horizontal structure of the functional-semantic locativity of the English and Azerbaijani languages, there are location and displacement micro-areas.

The grammatical level units of the field of functional-semantic locativeness of the Azerbaijani language consist of suffixes of spatial cases of the noun. The field has a grammatical core and, like grammatical tools, is distinguished by its high productivity in creating spatial meaning.

In English, spatial relations are traditionally studied on the basis of two types (directional relations, distance relations). The first type covers directional relations, is divided into external and internal directional relations. If external directional relations refer to the location of an object outside the landmark, internal directional relations include relations within 
the landmark. In distance relations, it covers the distance of the object from the object. The structure of the locative condition is the same or similar for different languages. In English, space-based envelope constructions have dependent components around the predicate. The approach relationship between the components of word combinations is typical. The basic model is in the form of a verb + apron + noun (in general). There is a well-defined sequence of words for analytical English. Therefore, the structure of the locative condition in English is concrete, consisting of subject, predicate and localizer.

\section{BIBLIOGRAPHY}

1. Abdullayev S. Müasir alman və Azərbaycan dillərində inkarlıq kateqoriyası. Bakı : Maarif, 1998, $279 \mathrm{~s}$.

2. Tahirov İ. Azərbaycan və ingilis dillərində zaman kateqoriyası. Bak1 : Nurlan, 2007, $324 \mathrm{~s}$.

3. Azərbaycan dilinin izahlı lüğəti. URL: // https://azerdict.com/az/izahli-luget/

4. Азизова М. Функционально-семантический подход к исследованию категории локативности в таджикском и английском языках. URL: https://cyberleninka.ru/article/n/funktsionalno-semanticheskiy-podhod-k-issledovaniyukateqorii-lokativnocti

5. Бондарко А. В. Принципы функциональной грамматики и вопросы аспектологии. Ленинград : Наука, 1983,208 с.

6. Бондарко А. В. Функциональная грамматика. Ленинград : Наука, 1984, 136 с.

7. Переверзев К. А. Пространства, ситуация, события, миры: К проблеме лингвистической онтологии. Логический анализ языка. Язык и пространства. Москва : Языки русской культуры, 2000. С. 255-267.

8. Уткин Д. В. Синонимическая словосочетания с пространственными значениями в современном русском языке. Вопросы морфологии и синтаксиса современного русского языка. Новосибирск : Зап. Сиб.кн. изд-во, 1966. C. 211-239.

9. Федосеева Л. Н. Функционально-семантическое поле локативности в современном языке: система языковых и контекстуальных значений. URL: https:/cyberleninka.ru/article/n/funktsionalno-semanticheskoe-pole-lokativnosti-vsovremennom-yazyke-sistema-yazykovyh-i-kontekstualnyh-znacheniy

10. Шмелев Д. Н. Проблемы семантического анализа лексики. Москва : Наука, 1973, 279 с.

11. Большой англо-русский словарь. Т. 2. Москва : Русский язык, 1988, 1072 с.

12. Гуревич Л. С. Когнитивное пространство метакоммуникации: основы прагмасемантического изучения : автореф. дис. ... д-ра филол. наук : 10.02.19. Москва, 2011. 33 с.

13. Чижова Л. А. Когнитивная категория локативности и различные способы её выражения в русском языке. Сборник научных трудов ІІІ Международной научной конференции «Современные проблемь славянской филологии глобализачия и обучение русскому языку». Москва, 2011. URL: http://istina.msu.ru/publications/article/5827167/

14. Черненко В. В., Моисенко А. А. О ядре микрополя местонахождения в функционально-семантическом поле «локативность» (на материале английского языка). Научная мысль Кавказа. 2010. № 2. С. 147-152.

15. Соловых Ю. С. Изучение категории пространство в современном научном знании. Вестник ОГУ. 2010. № 11(117). С. 129-132.

16. Саадулаева Р. Щ. Выражение пространственных отношений в лакском языке : автореф. дис. ... канд. филол. наук. Махачкала, 2013. С. 16-18.

17. Моаззен 3. 3. Категория русской именной локативности в зеркале персидского языка : дис. ... канд. филол. наук. Москва, 2010. 173 c. URL: http://www.dissercat.com/content/kategoriya-russkoi-immennoi-lokativnosti-v-zerkalepersidskogo-yazyka

18. Всеволодова М. В., Владимирский Е. Ю. Способы выражения пространственных отношений в современном русском языке. Москва : Либроком, 2009. 288 с.

\section{REFERENCES}

1. Abdullayev S. Müasir alman və Azərbaycan dillərində inkarlıq kateqoriyası [The category of negativeness in modern German and Azerbaijani languages. Baku: Maarif, 279 p. [in Azerbaijani].

2. Tahirov İ. Azərbaycan və ingilis dillərində zaman kateqoriyas1. [The category of time in Azerbaijani and English languages] Baku: Nurlan, 324 p. [in Azerbaijani].

3. Azərbaycan dilinin izahlı lüğəti [Explanatory dictionary of the Azerbaijani language] https://azerdict.com/az/izahliluget/ [in Azerbaijani].

4. Azizova M. Funktsional'no-semanticheskiy podkhod k issledovaniyu kategorii lokativnosti v tadzhikskom i angliyskom yazykakh. [Functional-semantic approach to the study of the category of locality in Tajik and English languages] Scientific notes of the Khujand State University named after academician B.Gafurov. Khujand: Humanitarian sciences, № 3. P. 147-156. https://cyberleninka.ru/article/n/funktsionalno-semanticheskiy-podhod-k-issledovaniyukateqorii-lokativnocti [in Russian].

5. Bondarko A. V. Printsipy funktsional'noy grammatiki i voprosy aspektologii. [Principles of functional grammar and aspects of aspectology] St. Petersburg: Science, 1983, 208 p. [in Russian].

6. Bondarko A. V. Funktsional'naya grammatika [Functional grammar] St. Petersburg: Science, 1984,36 p. [in Russian]

7. Pereverzev K. A. Prostranstva, situatsiya, sobytiya, miry: K probleme lingvisticheskoy ontologii [Spaces, Situation, Events, Worlds: On the Problem of Linguistic Ontology] Logical Analysis of Language. Language and space. Moscow: Languages of Russian culture, 2000. P. 255-267. [in Russian]. 
8. Utkin D. V. Sinonimicheskaya slovosochetaniya s prostranstvennymi znacheniyami v sovremennom russkom yazyke [Synonymous phrases with spatial meanings in the modern Russian language] Questions of morphology and syntax of the modern Russian language. Novosibirsk: Zap. Sib.kn. publishing house, 1966, Utkin D.V. P. 211-239 [in Russian].

9. Fedoseeva L. N. Funktsional'no-semanticheskoe pole lokativnosti v sovremennom yazyke: sistema yazykovykh i kontekstual'nykh znacheniy [Functional-semantic field of locality in a modern language: a system of linguistic and contextual meanings] Moscow: Questions of linguistics, № 2, pp. 43-49. https://cyberleninka.ru/article/n/funktsionalno-semanticheskoepole-lokativnosti-v-sovremennom-yazyke-sistema-yazykovyh-i-kontekstualnyh-znacheniy [in Russian].

10. Shmelev D. N. Problemy semanticheskogo analiza leksiki [Problems of semantic analysis of vocabulary] Moscow: Nauka, 1973, 279 p. [in Russian].

11. Bol'shoy anglo-russkiy slovar' [Comprehensive English-Russian Dictionary] T. 2. M .: Russian language, 1988, 1072 p.

12. Gurevich L. S. Kognitivnoe prostranstvo metakommunikatsii: osnovy pragmasemanticheskogo izucheniya [Cognitive space of metacommunication: the basics of pragmasemantic study] author. dis.... Doctor of Philological Sciences. 02/10/19. M., 2011.33 p. [in Russian].

13. Chizhova L. A. Kognitivnaya kategoriya lokativnosti i razlichnye sposoby ee vyrazheniya $\mathrm{v}$ russkom yazyke [The cognitive category of locality and various ways of expressing it in Russian] Collection of scientific papers of the III International scientific conference "Modern problems of Slavic philology - globalization and teaching the Russian language".M., 2011http://istina.msu.ru / publications / article / 5827167 [in Russian].

14. Chernenko V. V., Moisenko A. A. O yadre mikropolya mestonakhozhdeniya v funktsional'no- semanticheskom pole lokativnost' [On the core of the microfield of location in the functional-semantic field locativity (based on the English language)] Scientific Thought of the Caucasus. M., 2010, No. 2. P. 147-152.

15. Solovykh Yu. S. Izuchenie kategorii prostranstvo v sovremennom nauchnom znanii [Study of the category of space in modern scientific knowledge] Vestnik OSU. Orenburg: OSU edition, 2010, No. 11 (117), p. 129-132 [in Russian].

16. Saadulaeva R. Shch. Vyrazhenie prostranstvennykh otnosheniy v lakskom yazyke [Expression of spatial relations in the Lak language] author. dis ... cand. philological sciences. / R. Sch. Saadulaeva - Makhachkala, 2013. P. 16-18 [in Russian].

17. Moazzen Z. Z. Kategoriya russkoy imennoy lokativnosti v zerkale persidskogo yazyka [ Category of Russian nominal locativity in the mirror of the Persian language] dis ... cand. philological sciences. Moscow, 2010. $173 \mathrm{p}$. http://www.dissercat.com/content/kategoriya-russkoi-immennoi-lokativnosti-v-zerkale-persidskogo-yazyka [in Russian].

18. Vsevolodova M. V. Sposoby vyrazheniya prostranstvennykh otnosheniy v sovremennom russkom yazyke [Ways of expressing spatial relations in modern Russian language] M. V. Vsevolodova, E. Yu. Vladimirsky. M .: Librokom, 2009. 288 p. [in Russian]. 